\title{
A diabetes mellitus előfordulási gyakoriságának változása a malignus szájüregi daganatos betegek körében hosszútávú összehasonlító vizsgálat alapján
}

\author{
VÉGH DÁNIEL, BÁNYAI DOROTTYA*, DR. UJPÁL MÁRTA**
}

\begin{abstract}
A diabetes mellitus már világszerte népbetegségnek tekinthető, melynek prevalenciája hazánkban is eléri a 7\%-ot. Számos irodalmi adat bizonyítja, hogy a cukorbetegség elősegítő tényező a rosszindulatú daganatok kialakulásában is.

Munkacsoportunk korábban a diabetes előfordulási gyakoriságát vizsgálta malignus szájüregi daganatos betegek körében. Jelen retrospektív kutatásunkban a cukorbetegség és a szénhidrát-anyagcserezavar előfordulási gyakoriságát, valamint a szájüregi daganatok lokalizációját rögzítettük a klinikán 2012-2013-ban kezelt, szájüregi rákos betegcsoportban és eredményeinket összehasonlítottuk az 1998-1999-ben kapott adatokkal. Összehasonlító vizsgálatunkban a 267 szövettanilag igazolt szájüregi tumoros beteg között 59 esetben 22,1\%-ban diabetes mellitust, és 32 esetben 12\%ban emelkedett vércukorszintet találtunk. A leggyakoribb tumor-lokalizáció a cukorbetegeknél az ajaktumor volt, ezt követték a nyelv és a gingiva carcinomái. A 14 évvel ezelőtti adatokkal összehasonlítva a lokalizáció tekintetében lényeges változást nem tapasztaltunk, viszont a diabetes előfordulási gyakorisága 17,6\%-ról 22,1\%-ra, az emelkedett vércukorszint 9,8\%-ról 12\%-ra, a kóros glukóz regulációval rendelkező szájüregi tumorosok aránya pedig 27,4\%-ról 34,1\%-ra emelkedett $(p>0,05)$. Ezen bevezető vizsgálatunkkal e két kiemelten fontos betegségcsoport szoros kapcsolatát és a diabetes mellitus egyre szélesebb körü terjedését kívánjuk hangsúlyozni.
\end{abstract}

Kulcsszavak: diabetes mellitus, szájüregi daganatok, szájüregi rákok lokalizációja, rizikófaktorok

\section{Bevezetés}

A diabetes mellitus (DM) napjainkban már népbetegségnek tekinthető, melynek prevalenciája világszerte egyre növekszik.

Ez a tendencia észlelhető hazánkban is, ahol a 2013-as adatok alapján a cukorbetegség már a felnőtt lakosság kb. 7\%-át érinti, a korábbi 1999-es adatok 4-5\%-val szemben [1, 2, 9, 23]. A diabetes mellitus szájüregi szövődményei közül a fogágybetegség és a szájnyálkahártya elváltozások a leggyakoribbak, de nagyobb arányban fordul elő leukoplákia is ebben a betegcsoportban [15].

Munkacsoportunk 15 éve foglalkozik a cukorbetegség és a szájüregi daganatok összefüggéseinek vizsgálatával $[20,23,24]$. A nemzetközi irodalomban is - különösen az utóbbi években - egyre több olyan publikáció jelenik meg, amely bizonyítja, hogy a cukorbetegség elősegítő tényező a rosszindulatú daganatok, így az orális carcinomák kialakulása szempontjából és kedvezőtlenül befolyásolja a daganat progresszióját, valamint a túlélést [7, 10, 20, 25].

Korábbi epidemiológiai vizsgálataink egyike arra irányult, hogy milyen gyakorisággal fordul elő diabetes mel- litus és emelkedett éhomi vércukorérték a szájüregi rákos betegek között.

Jelen munkánkban arra a kérdésre kerestük a választ, hogy ha emelkedett a DM prevelanciája a hazai lakosság körében, vajon változott-e a kóros glukóz regulációval rendelkező betegek aránya a rosszindulatú szájüregi daganatos betegeknél, változott-e a szájüregi daganatok lokalizációja, és az eredmények összehasonlítása alapján milyen következtetések vonhatók le.

\section{Anyag és módszer}

Retrospektív vizsgálatot végeztünk a Semmelweis Egyetem Arc- Állcsont- Szájsebészeti és Fogászati Klinika fekvőbeteg osztályán 2012. január 1-jétől 2013. december 31-ig kezelt, szövettanilag igazolt szájüregi malignus daganatos betegek körében. Az 1998. január 1-je és 1999. december 31-e közötti azonos helyen végzett korábbi eredmények rendelkezésünkre álltak, ezek képezték az összehasonlítás alapját.

Az első időszak alatt 318 (219 férfi és 99 nő), a második, 14 évvel későbbi időszakban 267 (187 férfi és 78 nő) 
szövettanilag igazolt rosszindulatú daganatos beteg adatait dogoztuk fel.

Megvizsgáltuk a betegek éhgyomri vércukorértékét a klinikánkon vett vérminta alapján. Emelkedett vércukorértéket csak kontrollvizsgálattal igazolt esetben vettünk figyelembe. A vércukormérés minden alkalommal a SE I. Belgyógyászati Klinika Központi Laboratóriumában készült 717/912 Hitachi automatával.

A vércukorértékek alapján a WHO besorolás szerint a következő 3 csoportba soroltuk a betegeket:

1. normális éhgyomri vércukorszint $(6,1 \mathrm{mmol} / \mathrm{l}$ alatti)

2. emelkedett éhgyomri vércukorszint, szénhidrát-anyagcserezavar (IFG, impaired fasting glucose, 6,1-6,9 mmol//)

3. diabetes mellitus $(6,9 \mathrm{mmol} / \mathrm{l}$ feletti, illetve ismert, kezelt DM)

A statisztikai analízisben khi-négyzet próbát alkalmaztunk, a szignifikancia vizsgálatok 5\%-os szinten történtek.

\section{Eredmények}

A 267 rosszindulatú daganatban szenvedő betegből 176 betegnél $(65,9 \%)$ találtunk normális $(6,1 \mathrm{mmol} / \mathrm{l}$ alatti) vércukorszintet, 32 esetben (12\%) pedig emelkedett éhgyomri $(6,1-6,9 \mathrm{mmol} / \mathrm{l})$ vércukorszintet. Diabetesesnek 59 beteg $(22,1 \%)$ tekinthető. Vizsgálataink alapján két év szájüregi malignus tumoros beteganyagának 22,1\%-a diabeteses, $12 \%$-a pedig emelkedett éhgyomri vércukorszintǔ, tehát a vizsgált betegcsoport 34,1\%-a rendellenes cukorháztartással rendelkezik. A diabeteses betegek mindegyike a 2. típusú DM csoportba tartozott. A szájüregi rákok $91 \%$-a planocelluláris carcinoma, $8 \%$-a adenocarcinoma, $1 \%$-a mucoepidermoid carcinoma volt. A legtöbb malignus elváltozást az ajkakon találtuk (23 eset).

A korábbi vizsgálat szerint 318 rosszindulatú daganatban szenvedő betegből 231 betegnél $(72,7 \%)$ találtunk normális vércukorszintet, és 31 esetben $(9,8 \%)$ emelkedett éhgyomri vércukorszintet. A diabetesesek aránya $17,6 \%$ volt (56 beteg). A vizsgált betegcsoport 27,4\%-a

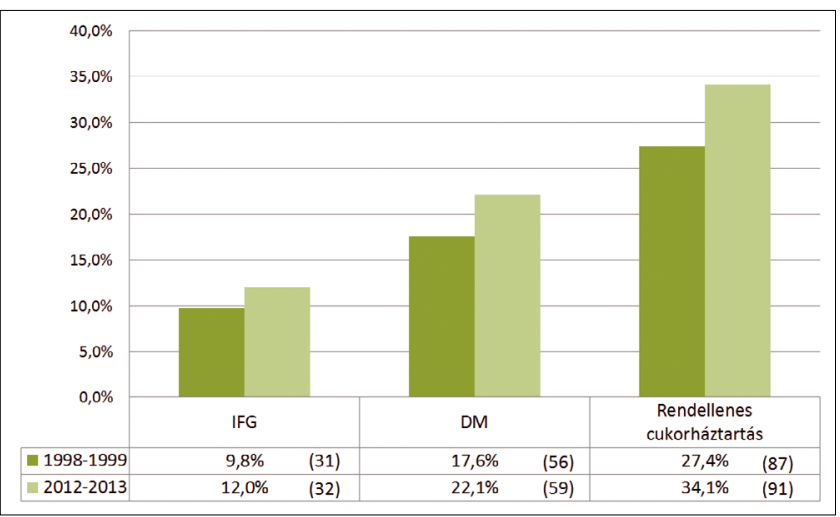

1. ábra: A diabetes mellitus és az IFG változása szájüregi daganatos betegek körében rendelkezett rendellenes cukorháztartással 14 évvel ezelőtt (1. ábra) és a daganatok $97 \%$-a bizonyult szövettanilag planocelluláris carcinomának. A diabeteses betegek körében a vizsgált periódusban ugyancsak az ajakrák volt a leggyakoribb (2. ábra).

\section{Megbeszélés}

A malignus tumorok és a DM világszerte komoly népegészségügyi problémát jelentenek. Különösen igaz ez hazánkra, mert az összes rosszindulatú daganatos halálozást és a szájüregi daganatok mortalitását tekintve is vezető szerepünk van Európában [18].

A szájüregi laphámrákok rossz prognózisúak, az ötéves túlélési arány még napjainkban sem mozdult el jelentősen az 50-55\%-os értékről [13, 19].

A DM és a rosszindulatú daganatok kapcsolatát számos publikáció igazolja $[7,8,14,26]$.

A fej-, nyak és a szájüregi daganatok is gyakoribbak diabetesesek körében. A DM a szájüregi carcinomák progresszióját is fokozza, tovább rontva az érintett betegcsoport amúgy is kedvezőtlen életkilátásait $[19,21]$.

A diabetesben zajló szöveti reakciók kedveznek a malignus daganatok terjedésének. A cukorbetegségcsoport rapidabb tumorterjedését több tényező is befolyásolhatja [21]. A 2-es típusú DM-ban tartós hyperglicaemia hatására az oxidációs egyensúly megbomlik, szabadgyökök szaporodnak fel, melyeket a diabetes miatt csökkent aktivitású antioxidáns rendszer nem képes eliminálni [3].

Az oxidációs egyensúly megváltozása oxidációs stressz kialakulásához vezet, emiatt glikált végtermékek halmozódnak fel (advanced glycation and products, AGE), melyek fokozott mértékben szabadgyökök, citokinek és növekedési faktorok felszabadulását okozzák, és károsítják az extracelluláris mátrix struktúrákat [16]. E folyamatok a bazálmembrán permeabilitás növekedését, ezáltal a tumorok terjedését segítik elő. Bizonyított tény, hogy a mátrix metalloproteinázok szintje DM-ban emel-

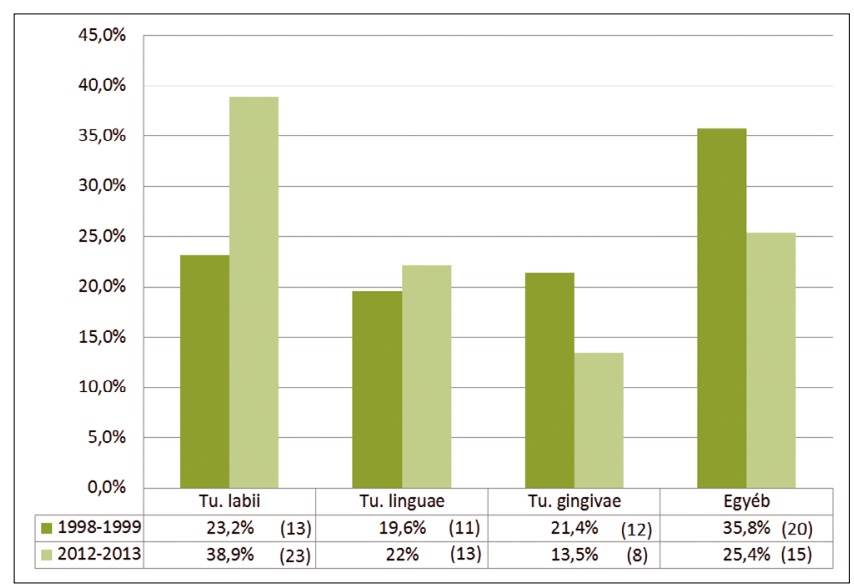

2. ábra: A diabeteses betegek szájüregi tumorának lokalizáció szerinti csoportosítása 
kedett, ami a tumorok lokális terjedésében, valamint az áttétképződésben játszik szerepet [6, 22].

A fokozottan glikált végtermékek emelik a RAGE (receptor for avanced glycation end products) expresszióját, amely a rákos sejtek inváziójának egyik szabályozója. Az orális carcinomák invazivitása szintén szoros öszszefüggést mutat a RAGE expressziójával [17]. A hyperglycaemia következtében a vér alakos elemeinek agglutinációja növekszik, amely mikroembolizációt, az érlumenek megvastagodását, elzáródását, majd szöveti hypoxiát okoz [12]. A tumorsejtek anyagcseréje során felerősödnek az anabolikus utak nem oxidatív lépései, emiatt azok hypoxiás körülmények között is képesek szaporodni [5]. DM-ban az emelkedett szöveti- és plazma-glukózszint jelentősen hozzájárulhat a proliferáló daganatsejtek replikációjához szükséges ribóz képzéséhez [4]. A Glut-1 glukóztranszporter jelentős szerepet játszik a hyperglycaemia okozta szövetkárosodásban és a carcinomák terjedésében. A Glut-1 expresszió mértéke és a szájüregi rákok következtében történő daganatos halálozás között szignifikáns összefüggés található: magasabb Glut-1 szintnél a várható túlélés rövidebb [11].

Összehasonlító epidemiológiai vizsgálatunk igazolja, hogy 14 év múltán emelkedett a szájüregi rákos csoportban a diabetesesek aránya 17,6\%-ról 22,1\%-ra. Kisebb mértékben, de növekvő értéket mutat az emelkedett vércukorszintű (IFG) betegek száma is, 9,8\%-ról $12 \%$-ra. Összesítésben a kóros cukorháztartással rendelkezők aránya 27,4\%-ról 34,1\%-ra nőtt, mely különbség a szignifikancia határértékét megközelíti, de nem éri el $(p>0,05)$.

A tumorok lokalizációját tekintve nem találtunk lényegi változást, leggyakoribbnak az ajak tumorai bizonyultak jelen és korábbi vizsgálatunkban is. Érdekesség viszont, hogy korábbi, nagyobb betegszámmal végzett felmérésünkben, amikor 610 szájüregi daganatos beteg adatát dolgoztuk fel, a gingiva tumorok fordultak elő legtöbbször és az ajak elváltozásai a második helyre szorultak [21, 22].

Ismert tény, hogy a dohányzó, alkoholizáló szájüregi carcinomások körében a leggyakoribbak a szájfenék és a nyelv tumorai [18]. A cukorbeteg csoportban ez a lokalizáció változik, aminek okai az eltérő kialakulási mechanizmusra vezethetők vissza. DM-ban, főleg a kezeletlen esetekben, csökken a nyálszekréciós ráta, gyakori a következményes cheilitis, glossitis, melyek talaján malignus elfajulás alakulhat ki.

A gingiva tumorok gyakorisága diabetesben pedig valószínúleg a parodontium chronikus gyulladásos folyamataira vezethető vissza, bár a szöveti anyagcserefolyamatok egyes részletei még ma sem ismertek teljesen. A dohányzás a diabeteseseknél is további súlyosbító tényező.

Munkánkat bevezetőnek és figyelemkeltőnek szántuk. További vizsgálatokat tervezünk a témával kapcsolatban nagyobb beteganyagon. Eddigi eredményeinkkel hangsúlyozni szeretnénk a két betegségcsoport szoros kapcsolatát és népegészségügyi jelentőségét.

\section{Irodalom}

1. Albrecht M, BÁnóczy J, Dinya E, et al: A szájnyálkahártya betegségek gyakorisága cukorbetegekben. Fogorv Szle 1996; 89: 385-394.

2. AlBRECHt M: Fog-és szájbetegségek diabetes mellitusban. Medicina 2001; 5-71.

3. BAynes JW, ThORPE SR: Role of of oxidative stress in diabetic complications: a new perspective in an old paradygm. Diabetes 1999; 48: 1-9.

4. Boros LG, Cascante M, Lee W-NP: Metabolic profilling of cell growth and death in cancer: applications in drug discovery. Drug Discov Today 2002; 7: 18-26.

5. Brennan PA, Mackenzie N, Quintero M: Hypoxia-inducible factor 1alpha in oral cancer. J Oral Pathol Med 2005; 34: 385-389.

6. Chen HH, Chen IH, Liao CT, Wel FC, Lee Ly, Huang SF: Preoperative circulating $\mathrm{C}$-reactive protein levels predict pathological aggressiveness in oral squamous cell carcinoma: a retrospective clinical study. Clin Otolaryngol 2011; 36: 147-153.

7. Faulds MH, Dahlman-Wright K: Metabolic diseases and cancer risk. Curr Opin Oncol 2012; 24: 58-61.

8. Goutzanis L, Vairaktaris E, Yapijakis C, Kavantzas N, Nkenke E, DERKA $S$, et al: Diabetes may increase risk for oral cancer through the insulin receptor substrate-1 and focal adhesion kinase pathway. Oral Oncol 2007; 43: 165-173.

9. http://www.idf.org/sites/default/files/EN_6E_Atlas_Full_0.pdf

10. Jancsik VA, Gelencser G, MaAsz G, Schmidt J, Molnar GA, WittMANN I, et al: Salivary proteomic analysis of diabetic parients for possible oral squamous cell carcinoma biomarkers. Pathol Oncol Res 2014; 20: 591-595.

11. Kunkel M, Reichert TE, Benz P: Over expression of Glut-1 and increased metabolism in tumors are associated with poor prognosis in patients with oral squamous cell carcinoma. Cancer 2003; 97: 1015-1024.

12. LORENZI M: Glucose toxicity in the vascular in the vascular complications of diabetes: the cellular perspective. Diab Metab Rev 1992; 8: 85-103.

13. NevilLe BW, Day TA: Oral cancer and precancerous lesions. $C A$ Cancer J Clin 2002; 52: 195-215.

14. Pandey A, Forte V, Abdallah M, Alickay A, Mahmud S, Asad S, MCFARLANE SI: Diabetes mellitus and the risk of cancer. Minerva Endocrinol 2011; 36: 187-209.

15. Saini R, Al Maweri SA, Saini D, Ismail NM, Ismail AR: Oral mucosal lesions in non oral habit diabetic patients and association of diabetes mellitus with oral precancerous lesions. Diabetes Res Clin Pract 2010; 89: 320-326.

16. Salahudeen AK, KanjI V, Reckelhoff JF: Pathogenesis of diabeticnephropathy: A radical approach. Nephrol Dial Transpl 1997; 12: 664-668.

17. Schmidt AM, Hori O, CaO R: RAGE - a novel cellular receptor for advanced glycation end products. Diabetes 1996; 45: 77-80.

18. Suba Zs, Mihály Sz, TaKács D, Gyulal-GaÁl Sz: Szájüregi rák: Morbus Hungaricus a 21. században. Fogorv Szle 2009; 102: 63-68.

19. Tseng KS, Lin C, Lin YS, Weng SF: Risk of Head and Neck Cancer in Patients With Diabetes Mellitus: A Retrospective Cohort Study in Taiwan. JAMA Otolaryngol Head Neck Surg 2014; 140: 1-8.

20. Ujpál M, Barabás J, Kovalszky I, Szabó G, Németh Z, Gábris K, et al: A preliminary comparative study of the prognostic implications of type 2 diabetes mellitus for patients with primary gingival carcinoma treated with surgery and radiation therapy. J Oral Maxillofac Surg 2007; 65: 452-456.

21. Ujpál M, Barabás J, Szabó Gy, Bogdán S, Lörincz Á, Suba Zs: A 2. típusú diabetes mellitus prognosztikai jelentősége a sebészileg kezelt és irradiált gingiva carcinomás betegeknél. Fogorv Szle 2007; 100: 99-102.

22. Ujpál M, Matos O, Bíbok G, Somogyı A, Szabó G, Suba Z: Diabetes and oral tumors in Hungary:epidemiological correlations. Diabetes Care 2004; 27: 770-774. 
23. Ujpál M, Matos O, Вíbok G, Somogy A, Szigetı K, Szabó G, et al: Diabetes mellitus and tumors of the oral cavity - epidemiologic correlations. Orv Hetil 2004; 145: 755-759.

24. Ujpál M, Matos O, Bíbok Gy, Szabó Gy: A diabetes mellitus elöfordulása malignus szájüregi daganatos betegekben. Orv Hetil 2002; 143: 2731-2733.
25. Vairaktaris E, Spyridonidou S, Goutzanis L, Vyluiotis A, Lazaris A, DonTA I, et al: Diabetes and oral oncogenesis. Anticancer Res 2007; 27: 4185-4193.

26. Wu CH, Wu TY, LI CC, LUI MT, Chang KW, KaO SY: Impact of diabetes mellitus on the prognosis of patients with oral squamous cell carcinoma: a retrospective cohort study. Ann Surg Oncol 2010; 17: 2175-2183.

\section{VÉGH D, BÁNYAI D, UJPÁL M \\ The change of the incidence of diabetes mellitus in oral cancer patients based on long-term follow-up studies}

Our research is focused on the incidence of diabetes mellitus and glucose metabolic disorders among oral cancer patients and the frequency of different oral localizations of cancer. Diabetes mellitus affects $7 \%$ of the Hungarian population.

This study uses data spanning 14 years, with 2 datasets of 1998-1999 and 2012-2013, collected first hand by the authors.

These datasets have led us to examine the blood glucose level in 267 patients with histologically confirmed malignant tumours in the oral cavity. Diabetes mellitus was found in 59 of them $(22,1 \%)$, The blood glucose was elevated in 32 cases $(12 \%)$. The most frequent tumor locations among the diabetic patients: labial, lingual and gingival tumors gingivae. Comparative epidemiological study demonstrates that in 2012-2013 dataset there was an increased observed percentage of people with diabetes mellitus [17,6\% to $22,1 \%$ ]. The percentage of patients with IFG (impaired fasting glucose) also increased from $9,8 \%$ to $12 \%$. Overall the number of patients with glucose metabolic disorders climbed from $27,4 \%$ to $34,1 \%$, ( $p>0,05)$.

Our intention of this introductory analysis is to emphasize the close connection of these two very important disease groups, and the wider spread of diabetes mellitus.

Keywords: diabetes mellitus, oral carcinoma, locations of oral cancer, risk factors 